\title{
Mercury in Macrolepiota procera (Scop.) Singer and Its Underlying Substrate-Environmental and Health Risks Assessment
}

\author{
Ivona Jančo $^{1, *}$, Marek Šnirc ${ }^{1}$, Martin Hauptvogl ${ }^{2}$, Lenka Demková ${ }^{3} \mathbb{D}$, Hana Franková ${ }^{1}$, Vladimír Kunca $^{4}$, \\ Tomáš Lošák ${ }^{5}$ and Július Árvay ${ }^{1}$ D
}

1 Department of Chemistry, Faculty of Biotechnology and Food Sciences, Slovak University of Agriculture in Nitra, 94976 Nitra, Slovakia; marek.snirc@uniag.sk (M.Š.); xchrkavah@uniag.sk (H.F.); julius.arvay@gmail.com (J.Á.)

2 Faculty of European Studies and Regional Development, Institute of Environmental Management, Slovak University of Agriculture in Nitra, 94976 Nitra, Slovakia; martin.hauptvogl@uniag.sk

3 Department of Ecology, Faculty of Humanities and Natural Sciences, University of Prešov, 08116 Prešov, Slovakia; lenka.demkova@unipo.sk

4 Department of Applied Ecology, Faculty of Ecology and Environmental Sciences, Technical University in Zvolen, 96001 Zvolen, Slovakia; kunca@tuzvo.sk

5 Department of Environmentalistics and Natural Resources, Faculty of Regional Development and International Studies, Mendel University in Brno, 61300 Brno, Czech Republic; tomas.losak@mendelu.cz

* Correspondence: xjanco@uniag.sk; Tel.: +421-376414375

\section{check for} updates

Citation: Jančo, I.; Šnirc, M.; Hauptvogl, M.; Demková, L.; Franková, H.; Kunca, V.; Lošák, T.; Árvay, J. Mercury in Macrolepiota procera (Scop.) Singer and Its Underlying SubstrateEnvironmental and Health Risks Assessment. J. Fungi 2021, 7, 772. https://doi.org/10.3390/jof7090772

Academic Editors: Monika Gąsecka and Zuzanna Magdziak

Received: 19 July 2021

Accepted: 14 September 2021

Published: 18 September 2021

Publisher's Note: MDPI stays neutral with regard to jurisdictional claims in published maps and institutional affiliations.

Copyright: (c) 2021 by the authors. Licensee MDPI, Basel, Switzerland. This article is an open access article distributed under the terms and conditions of the Creative Commons Attribution (CC BY) license (https:// creativecommons.org/licenses/by/ $4.0 /)$.
Abstract: Wild-growing edible mushrooms are valuable food with a high content of proteins, fibers, antioxidants, and they are characterized by their specific taste and flavor. However, from an ecotoxicological point of view, they are a risk commodity because of their extremely high bioaccumulative capacity to accumulate the risk elements and contaminants from the environment. In the present study, we examined mercury ( $\mathrm{Hg}$ ) contamination in 230 fruiting bodies of Macrolepiota procera (Scop.) Singer and 230 soil/substrate samples, which were collected in foraging seasons 2015-2019 from 22 different locations in Slovakia. Total mercury content was determined by cold-vapor AAS analyzer AMA 254. The level of contamination and environmental risks were assessed by contamination factor $\left(\mathrm{C}_{\mathrm{f}}\right)$, index of geoaccumulation $\left(\mathrm{I}_{\mathrm{geo}}\right)$, and potential environmental risk index (PER). Bioaccumulation factor (BAF) was calculated for individual anatomical parts of $M$. procera. Mercury content in the soil/substrate samples varied between 0.02 and $0.89 \mathrm{mg} \mathrm{kg}^{-1} \mathrm{DW}$, and in mushroom samples between 0.03 and $2.83 \mathrm{mg} \mathrm{kg}^{-1} \mathrm{DW}$ (stems), and between 0.04 and $6.29 \mathrm{mg} \mathrm{kg}^{-1} \mathrm{DW}$ (caps). The obtained results were compared with the provisional tolerable weekly intake for $\mathrm{Hg}$ defined by WHO to determine a health risk resulting from regular and long-term consumption of M. procera.

Keywords: Macrolepiota procera; mercury; bioaccumulation; contamination

\section{Introduction}

Nowadays, mushrooms are considered valuable foods, not only because of their attractive sensory characteristics and their culinary features but also for their nutritional properties [1]. From an environmental point of view, mushrooms have a positive impact on increasing soil fertility through their ability to break down and dissolve complex compounds into simple ones, as well as the ability to reduce or eliminate environmental pollutants [2,3]. Mushrooms (mainly ectomycorrhizal macrofungi) can accumulate high amounts of potentially harmful elements, especially when collected from heavily contaminated regions (mining sites, industrial areas) or soils with high metal content $[4,5]$. Mushrooms grown in such conditions are toxic and non-edible [6,7].

The accumulation of risk elements by mushrooms is a complex process affected by both environmental and intrinsic factors [8]. The mycelia of mushrooms spread over large 
areas (several square meters) and their relationships with soil and dead organic matter, as well as their symbiotic relationship with plant roots, allow an intensive exchange with substrates. Risk element content in many mushroom species correlates with the high metal content in the soil they grow in. Some authors report higher metal contents in immature fruiting bodies than in adult ones, which is explained by the transport of metal ions from the mycelium to the fruiting body occurring predominantly at the beginning of the fructification [9]. There is growing evidence that mushrooms can be suitable for biogeochemical prospecting for minerals as well as indicators of risk elements and radioactive contaminants in the terrestrial environment. Knowledge of accumulation dynamics and distribution of elements in fruiting bodies, from emergence to senescence, is essential as is standardization when choosing mushroom species as potential bioindicators and for monitoring purposes [10]. The morphological differences for different taxa in their early development would strongly suggest implications to physiology and therefore to the distribution of elements. Furthermore, fruiting body expansion may be accomplished both by cell division and, more frequently, by the expansion of existing cells which is typically achieved through rapid water uptake. Therefore, the existing variety of primordial growth may partly explain the unpredictable pattern of elemental distribution reported in the literature. The metallic and metalloid elements accumulated by the ectomycorrhizal fungi mycelium are thought to be taken up passively or actively from soil solution and substrate. Once absorbed, they are used by the mycelium and partly supplied to the ectomycorrhizal symbiont(s). Knowledge of the characteristics of minerals accumulated by fungi helps in understanding ecosystem functioning and contributes to an explanation of the nutritional value of edible species [11].

Macrolepiota procera, known under the common name Parasol Mushroom, formerly called Lepiota procera, prefers light and warm places, especially calcareous and sandy soils that are well-drained in forests, meadows, and gardens [12,13]. It is a soil-inhabiting saprophytic species growing alone, scattered in woods, at the edges of woods, or in pastures [12]. It is popular in Europe, and its cap is edible and tasty [12]. Parasol Mushroom has low-fat content and high content of proteins and minerals [14]. The species, like certain other macromycetes, is efficient in accumulating toxic mercury $(\mathrm{Hg})$, cadmium $(\mathrm{Cd})$, lead $(\mathrm{Pb})$, silver $(\mathrm{Ag})$, and some micronutrients in fruiting bodies. Due to its bioaccumulation ability, many researchers investigate metalloids and toxic metals contents in the fruiting bodies of Macrolepiota species commonly collected by locals for their essential micro- and macroelements [12].

Mercury, unlike other risk metals, can remain in the atmosphere and soil for the long-term and it can be distributed or migrate over long distances [15]. Sources of mercury pollution in soil include atmospheric deposition, sewage irrigation, livestock manure, and discarded mercury-containing appliances [16]. Inorganic mercury in the environment can be converted to highly neurotoxic methyl mercury (MeHg) [17]. Mercury ranks among the most frequently determined elements in mushrooms. M. procera and some other species are mercury bioaccumulators [18]. After entering the human body, mercury exerts a variety of adverse effects on human body organs, e.g., kidney, liver, respiratory system, skin, nervous systems and immune system, reproductive and developmental defects, genotoxicities, and cardiovascular disorders [19].

The present study aims to determine the level of mercury contamination of M. procera and soil/substrate samples. Ecological risks of $\mathrm{Hg}$ were evaluated by calculating contamination factor, index of geoaccumulation, potential environmental risk index, as well as the bioaccumulation factor. Third, to assess the health risk resulting from the consumption of the studied mushroom by applying provisional tolerable weekly intake. 


\section{Materials and Methods}

\subsection{Statistical Analysis and Data Processing}

Table 1 summarizes the GPS coordinates of the sampling areas and the number of samples. The data were processed in the open-source QGIS software (v3.10; multilevel B-spline interpolation method).

Table 1. Basic characteristics of the sampling areas.

\begin{tabular}{ccccc}
\hline Locality & $\mathbf{n}$ & \multicolumn{2}{c}{$\begin{array}{c}\text { Coordinates } \\
\text { (VGS 84) }\end{array}$} & $\begin{array}{c}\text { Altitude } \\
\text { (m) }\end{array}$ \\
\hline Bojná & 15 & 48.591916 & 18.021600 & 390 \\
Divina & 6 & 49.286883 & 18.691366 & 423 \\
Duchonka & 9 & 48.663350 & 18.094166 & 275 \\
Hodruša-Hámre & 21 & 48.468566 & 18.755716 & 409 \\
Jedl'ové Kostol'any & 9 & 48.495283 & 18.454450 & 420 \\
Krajné & 15 & 48.707103 & 17.688867 & 289 \\
Král'ovce & 20 & 48.326200 & 18.986500 & 229 \\
Lazy pod Makytou & 12 & 49.244400 & 18.225650 & 542 \\
Limbach & 7 & 48.294658 & 17.200095 & 420 \\
Lozorno & 8 & 48.335600 & 17.063083 & 220 \\
Nemečky & 6 & 48.683833 & 18.105333 & 298 \\
Orovnica & 8 & 48.366516 & 18.575166 & 254 \\
Pezinská Baba & 8 & 48.337583 & 17.200451 & 537 \\
Pitelová & 5 & 48.618097 & 18.913429 & 480 \\
Sitnianska Lehôtka & 20 & 48.312333 & 18.961416 & 232 \\
Skýcov & 10 & 48.476183 & 18.454166 & 473 \\
Snina & 7 & 48.976100 & 22.194766 & 260 \\
Solčany & 8 & 48.537475 & 18.198736 & 385 \\
Šachtička & 6 & 48.803309 & 19.150328 & 1009 \\
Štiavnik & 6 & 49.312900 & 18.412250 & 655 \\
Tesáre & 15 & 48.604333 & 18.073000 & 251 \\
Zbyňov & 9 & 49.124650 & 18.639466 & 378 \\
\hline
\end{tabular}

\subsection{Study Areas, Sampling, and Sample Preparation}

This study was carried out in Slovakia in 22 different locations (Figure 1).

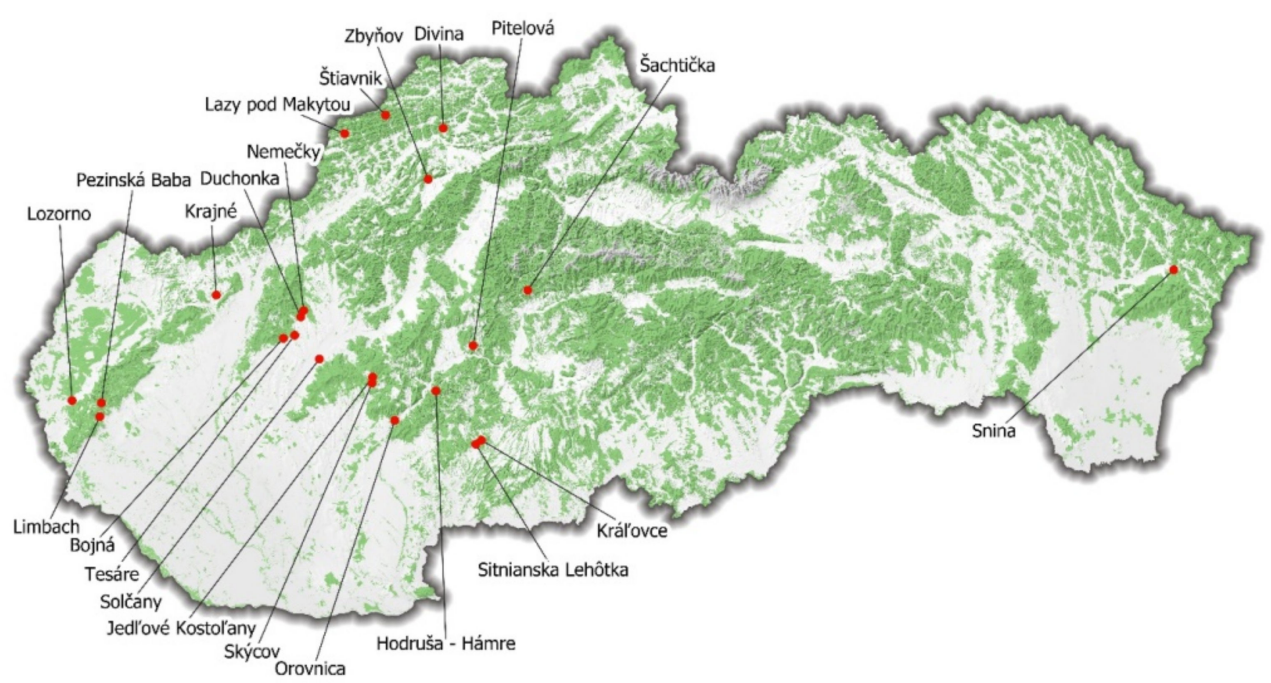

Figure 1. Mushroom and its underlying soil sampling localities in Slovakia.

Directly after the sampling, all mushroom samples $(n=230)$ were cleaned up from any organic and inorganic debris and the bottom part of the stem was cut off. After 
that, they were divided into two parts: cap and stem. The individual cap and stem samples were sliced into pieces using a ceramic knife and dried to a constant weight at $45^{\circ} \mathrm{C}$ in a laboratory dry heat-oven with forced air circulation (Memmert $\mathrm{GmbH} \&$ Co. KG, Schwabach, Germany) for $22 \mathrm{~h}$. The dried samples were pulverized in the rotary homogenizer (IKA Mills A 10 basic -Werke GmbH \& Co. KG, Staufen, Germany) and stored in polyethylene bags until further analysis. Soil/substrate samples $(n=230)$ were collected together with mushroom samples at the same location from a depth of approximately $0.10 \mathrm{~m}$. Under the laboratory conditions, the samples were air-dried at room temperature for 3 weeks. Afterward, they were sieved through a mesh sieve $(2 \mathrm{~mm})$ and stored in paper bags until the analysis.

\subsection{Sample Analysis}

Total mercury content was determined by cold-vapor AAS analyzer AMA 254 (Altec, Prague, Czech Republic), in all types of dried and homogenized samples (separately in 230 cap, stem, and soil/substrate samples (690 samples in total)). The limit of detection for $\mathrm{Hg}$ was set at $1.5 \times 10^{-6} \mathrm{mg} \mathrm{kg}^{-1} \mathrm{DW}$ and the limit of quantification at $4.45 \times 10^{-6} \mathrm{mg} \mathrm{kg}^{-1} \mathrm{DW}$. Two Certified Reference Materials (CRM) from the Institute for Reference Materials and Measurements were used to check the accuracy and precision of the analytical method. The recovery value for the loam soil (ERM-CC141), varied between 0.06 and $0.07 \mathrm{mg} \mathrm{kg}^{-1} \mathrm{DW}$, and for the Mussel tissue (ERM-CE278k), it varied between 0.05 and $0.06 \mathrm{mg} \mathrm{kg}^{-1} \mathrm{DW}$.

\subsection{Risk Assessment}

To assess the level of ecological load of the monitored localities, we evaluated the $\mathrm{Hg}$ content in the soil/substrate using the following parameters:

Contamination factor $\left(C_{f}^{i}\right)$ described by [20] was used to express the level of soil/substrate pollution by mercury. It is calculated as follows:

$$
C_{f}^{i}=\frac{C_{0-1}^{i}}{C_{n}^{i}}
$$

where: $C_{0-1}^{i}$ is the total $\mathrm{Hg}$ content in soil and $C_{n}^{i}$ is the background $\mathrm{Hg}$ level, which is $\left(0.06 \mathrm{mg} \mathrm{kg}^{-1}\right)$ [21]. The contamination factor values are divided into four categories: low contamination factor $\left(C_{f}^{i}<1\right)$; moderate contamination factor $\left(1 \leq C_{f}^{i}<3\right)$; considerable contamination factor $\left(3 \leq C_{f}^{i}<6\right)$; very high contamination factor $\left(C_{f}^{i} \geq 6\right)$.

Ecological risk assessment is assessed by the potential ecological risk index (PER, or RI). PER expresses the amount of potential ecological risk factor for the given risk element $\left(E_{r}^{i}\right)[20]:$

$$
\mathrm{PER}_{\mathrm{Hg}}=E_{r}^{i}
$$

where: $E_{r}^{i}$ is the potential ecological risk factor of a single element $(\mathrm{Hg})$. The degree of ecological risk can be categorized as follows: $E_{r}^{i}<40$ : low risk; $40 \leq E_{r}^{i}<80$ : moderate risk; $80 \leq E_{r}^{i}<160$ : considerable risk; $160 \leq E_{r}^{i}<320$ : high risk; $E_{r}^{i} \geq 320$ : very high risk [22,23].

To quantify the level of contamination on the sampling localities the geo-accumulation index $\left(\mathrm{I}_{\text {geo }}\right)$ was calculated:

$$
\mathrm{I}_{\text {geo }}=\log _{2}(\mathrm{Cn} / 1.5 \times \mathrm{Bi})
$$

where: $\mathrm{Cn}$ is the $\mathrm{Hg}$ content in the soil samples, 1.5 is the constant that is used due to potential variations in the baseline data (characterizes the depositional feature, rock geology, and other effects) and $B i$ is the background value of $\mathrm{Hg}\left(0.06 \mathrm{mg} \mathrm{kg}^{-1}\right)$ [21]. The $\mathrm{I}_{\text {geo }}$ values are divided into seven categories [24]: background values ( $\left.\mathrm{I}_{\text {geo }} \leq 0\right)$; uncontaminated $\left(0<\right.$ Igeo $\left._{\text {ge }}<1\right)$; uncontaminated or slightly contaminated $\left(1 \leq \mathrm{I}_{\text {geo }}<2\right)$; slightly contaminated $\left(2 \leq \mathrm{I}_{\text {geo }}<3\right)$; moderately contaminated $\left(3 \leq \mathrm{I}_{\text {geo }}<4\right)$; strongly contaminated $\left(4 \leq \mathrm{I}_{\text {geo }}<5\right)$; very strongly contaminated $\left(I_{\text {geo }} \geq 5\right)$. 
Bioaccumulation factor (BAF) was calculated to assess the level of transition and accumulation of $\mathrm{Hg}$ from soil/substrate to the above-ground parts (fruiting body) of $M$. procera. It was calculated as follows:

$$
\mathrm{BAF}=\frac{C_{H g}}{C_{s}}
$$

where: $C_{H g}$ is the measured mercury content mushroom samples and $C_{s}$ is the measured mercury content in soil/substrate. BAF $<1$ indicates excluders, BAF $>1$ indicates accumulators [25]. The cap/stem quotient $\left(\mathrm{Q}_{\mathrm{c} / \mathrm{s}}\right)$ was evaluated to compare the level of $\mathrm{Hg}$ translocation within the fruiting body.

\subsection{Health Risk Assessment}

Provisional Tolerable Weekly Intake-PTWI

The percentage of the provisional tolerable weekly intake (PTWI) assesses the health risk from exposure to each toxic element. The tolerable weekly intake per person weighing $70 \mathrm{~kg}$ for $\mathrm{Hg}$ is $0.28 \mathrm{mg}$ per person per week [26]. Taking into account the average consumption of "Other vegetables and mushrooms" in Slovakia that was $0.23 \mathrm{~kg}$ FW per person per week in 2018 [27] the percentage of PTWI was calculated as follows:

$$
\operatorname{PTWI}(\%)=\frac{\mathrm{BS}_{\mathrm{HG}} \times 0.23}{0.28} \times 100
$$

where: $\mathrm{BS}_{\mathrm{Hg}}$ is the measured content of $\mathrm{Hg}$ in the biological sample $\left(\mathrm{mg} \mathrm{kg}^{-1}\right.$ of fresh weight (FW) in mushrooms). If the detected value was greater than $100 \%$, the consumption of mushroom samples from the area is potentially hazardous.

\subsection{Statistical Analysis}

All statistical operations were performed using R studio version 1.2.5033 [28]. Spearman's correlation analysis was used to determine the correlation relationship (negative or positive) between tested variables, soil/substrate, and mushroom, with a significant level $p<0.05$ [29]. The Kruskal-Wallis test with multiple pairwise comparisons using the Wilcox test was used to identify significant differences between tested variables at the significance level of $5 \%$, using the $p$-value.

\section{Results and Discussion}

\subsection{Mercury in Soil/Substrate Samples}

Soil/substrate represents the main source of nutrients as well as risk elements (e.g., $\mathrm{Hg}$ ) for the mycelium and mushroom's fruiting body. When compared with the fruiting bodies, the soil/substrate contains mercury in minor contents. Mercury content in soil/substrate and mushroom samples (stem and cap) is shown in Table 2.

Hodruša-Hámre, Jedl'ové Kostol'any, Krajné, Sitnianska lehôtka, Snina, Šachtička, Štiavnik and Zbyňov belong to the 1st environmental region quality (regions with unisturbed environment), while Bojná, Divina, Duchonka, Král'ovce, Limbach, Lozorno, Nemečky, Orovnica, Pezinská Baba, Pitelová, Skýcov, Solčany and Tesáre) belong to the 2nd environmental region quality (regions with moderately disturbed environment).

In Slovakia, the background $\mathrm{Hg}$ content in the soil is $0.06 \mathrm{mg} \mathrm{kg}^{-1}$ [21]. The average mercury content in the soil/substrate in the study areas varied between 0.04 and $0.68 \mathrm{mg} \mathrm{kg}^{-1} \mathrm{DW}$ (Figure 2). The highest average $\mathrm{Hg}$ content was detected in Snina $\left(0.68 \pm 0.19 \mathrm{mg} \mathrm{kg}^{-1} \mathrm{DW}\right)$ and the lowest in Lozorno $\left(0.04 \pm 0.02 \mathrm{mg} \mathrm{kg}^{-1} \mathrm{DW}\right)$. 
Table 2. Mercury content in soil/substrate and mushroom samples and ecological and health risk indices.

\begin{tabular}{|c|c|c|c|c|c|c|c|c|c|c|c|}
\hline \multirow[b]{2}{*}{$\begin{array}{l}\text { Sampling } \\
\text { Locality }\end{array}$} & \multicolumn{4}{|c|}{ Soil/Substrate } & \multicolumn{6}{|c|}{ Mushroom } & \multirow[b]{2}{*}{$\%$ PTWI $_{\text {stem }}$} \\
\hline & $\begin{array}{c}\text { Hg } \\
\left(\mathrm{mg} \mathrm{kg}^{-1} \text { DW) }\right. \\
\text { AVG } \pm \text { S.D. } \\
\text { Min-Max }\end{array}$ & Igeo * & $C f^{*}$ & PER * & $\begin{array}{c}\mathrm{Hg}_{\text {cap }} \\
\left(\mathrm{mg} \mathrm{kg}^{-1} \text { DW) }\right. \\
\text { AVG } \pm \text { S.D. } \\
\text { Min-Max }\end{array}$ & $\begin{array}{c}\mathrm{Hg}_{\text {stem }} \\
\left(\mathrm{mg} \mathrm{kg}^{-1} \mathrm{DW}\right) \\
\mathrm{AVG} \pm \text { S.D. } \\
\text { Min-Max }\end{array}$ & $\mathrm{BAF}_{\text {cap }}$ * & $\mathbf{B A F}_{\text {stem }}$ * & $\mathrm{Q}_{\mathrm{c} / \mathrm{s}}$ * & \%PTWI cap $^{*}$ & \\
\hline Bojná & $\begin{array}{c}0.09 \pm 0.03 \\
0.03-0.15\end{array}$ & 1.41 & -0.20 & 56.5 & $\begin{array}{c}2.09 \pm 1.17 \\
0.06-4.57\end{array}$ & $\begin{array}{c}1.00 \pm 0.46 \\
0.05-1.55\end{array}$ & 24.7 & 11.7 & 2.10 & 61.3 & 29.2 \\
\hline Divina & $\begin{array}{c}0.13 \pm 0.02 \\
0.11-0.16\end{array}$ & 2.23 & 0.56 & 89.3 & $\begin{array}{c}3.57 \pm 1.66 \\
1.84-6.29\end{array}$ & $\begin{array}{c}1.75 \pm 0.66 \\
0.84-2.70\end{array}$ & 26.6 & 13.0 & 2.04 & 105 & 51.2 \\
\hline Duchonka & $\begin{array}{c}0.11 \pm 0.05 \\
0.05-0.18\end{array}$ & 1.79 & 0.12 & 71.6 & $\begin{array}{c}1.89 \pm 0.67 \\
0.75-3.01\end{array}$ & $\begin{array}{c}1.18 \pm 0.29 \\
0.65-1.61\end{array}$ & 17.6 & 10.9 & 1.61 & 55.3 & 34.5 \\
\hline Hodruša-Hámre & $\begin{array}{c}0.07 \pm 0.03 \\
0.03-0.14\end{array}$ & 1.10 & -0.54 & 44.1 & $\begin{array}{c}1.07 \pm 0.60 \\
0.07-2.86\end{array}$ & $\begin{array}{c}0.69 \pm 0.36 \\
0.04-1.59\end{array}$ & 16.2 & 10.5 & 1.55 & 31.5 & 20.3 \\
\hline $\begin{array}{c}\text { Jedl'ové } \\
\text { Kostol'any }\end{array}$ & $\begin{array}{c}0.08 \pm 0.03 \\
0.04-0.11\end{array}$ & 1.31 & -0.30 & 52.6 & $\begin{array}{c}1.64 \pm 1.49 \\
0.77-5.75\end{array}$ & $\begin{array}{c}0.91 \pm 0.61 \\
0.49-2.51\end{array}$ & 20.8 & 11.5 & 1.81 & 48.2 & 26.6 \\
\hline Krajné & $\begin{array}{c}0.10 \pm 0.06 \\
0.05-0.27\end{array}$ & 1.71 & 0.00 & 68.2 & $\begin{array}{c}1.94 \pm 0.49 \\
1.16-2.95\end{array}$ & $\begin{array}{c}1.31 \pm 0.42 \\
0.45-1.82\end{array}$ & 19.0 & 12.8 & 1.49 & 57.0 & 38.3 \\
\hline Král'ovce & $\begin{array}{c}0.06 \pm 0.02 \\
0.04-0.11\end{array}$ & 0.94 & -0.73 & 37.5 & $\begin{array}{c}0.89 \pm 0.30 \\
0.44-1.72\end{array}$ & $\begin{array}{c}0.73 \pm 0.23 \\
0.44-1.59\end{array}$ & 15.7 & 13.0 & 1.21 & 26.0 & 21.5 \\
\hline $\begin{array}{l}\text { Lazy pod } \\
\text { Makytou }\end{array}$ & $\begin{array}{c}0.09 \pm 0.02 \\
0.06-0.13\end{array}$ & 1.53 & -0.02 & 61.1 & $\begin{array}{c}2.28 \pm 0.87 \\
1.22-4.00\end{array}$ & $\begin{array}{c}1.46 \pm 0.64 \\
0.67-2.83\end{array}$ & 24.9 & 16.0 & 1.56 & 66.9 & 42.9 \\
\hline Limbach & $\begin{array}{c}0.07 \pm 0.04 \\
0.02-0.12\end{array}$ & 1.19 & -0.61 & 47.5 & $\begin{array}{c}2.73 \pm 1.28 \\
1.58-5.16\end{array}$ & $\begin{array}{c}1.64 \pm 0.60 \\
0.92-2.70\end{array}$ & 38.3 & 23.1 & 1.66 & 80.0 & 48.2 \\
\hline Lozorno & $\begin{array}{c}0.04 \pm 0.02 \\
0.02-0.07\end{array}$ & 1.10 & -0.74 & 43.8 & $\begin{array}{c}1.59 \pm 0.88 \\
0.04-2.86\end{array}$ & $\begin{array}{c}1.19 \pm 0.69 \\
0.03-2.17\end{array}$ & 43.9 & 33.0 & 1.33 & 46.5 & 34.9 \\
\hline
\end{tabular}


Table 2. Cont.

\begin{tabular}{|c|c|c|c|c|c|c|c|c|c|c|c|}
\hline \multirow[b]{2}{*}{$\begin{array}{c}\text { Sampling } \\
\text { Locality }\end{array}$} & \multicolumn{4}{|c|}{ Soil/Substrate } & \multicolumn{6}{|c|}{ Mushroom } & \multirow[b]{2}{*}{$\% \mathrm{PTWI}_{\text {stem }}$} \\
\hline & $\begin{array}{c}\mathrm{Hg} \\
\left(\mathrm{mg} \mathrm{kg}^{-1} \mathrm{DW}\right) \\
\mathrm{AVG} \pm \text { S.D. } \\
\text { Min-Max }\end{array}$ & Igeo * & $\mathrm{Cf}^{*}$ & PER * & $\begin{array}{c}\mathrm{Hg}_{\text {cap }} \\
\left(\mathrm{mg} \mathrm{kg}^{-1} \mathrm{DW}\right) \\
\mathrm{AVG} \pm \text { S.D. } \\
\text { Min-Max }\end{array}$ & $\begin{array}{c}\mathrm{Hg}_{\text {stem }} \\
\left(\mathrm{mg} \mathrm{kg}^{-1} \mathrm{DW}\right) \\
\mathrm{AVG} \pm \text { S.D. } \\
\text { Min-Max }\end{array}$ & $\mathbf{B A F}_{\text {cap }}$ * & $\mathrm{BAF}_{\text {stem }}$ * & $\mathrm{Q}_{\mathrm{c} / \mathrm{s}}{ }^{*}$ & $\%$ PTWI $_{\text {cap }}$ * & \\
\hline Nemečky & $\begin{array}{c}0.11 \pm 0.03 \\
0.07-0.17\end{array}$ & 1.15 & -0.38 & 46.1 & $\begin{array}{c}1.03 \pm 0.26 \\
0.49-1.37\end{array}$ & $\begin{array}{c}0.73 \pm 0.16 \\
0.58-1.04\end{array}$ & 9.76 & 6.95 & 1.40 & 30.1 & 21.5 \\
\hline Orovnica & $\begin{array}{c}0.07 \pm 0.00 \\
0.06-0.08\end{array}$ & 1.82 & 0.16 & 72.9 & $\begin{array}{c}1.43 \pm 0.41 \\
0.95-2.15\end{array}$ & $\begin{array}{c}0.79 \pm 0.22 \\
0.51-1.15\end{array}$ & 20.8 & 11.5 & 1.81 & 42.1 & 23.3 \\
\hline Pezinská Baba & $\begin{array}{c}0.12 \pm 0.04 \\
0.07-0.19\end{array}$ & 1.52 & -0.12 & 60.9 & $\begin{array}{c}2.81 \pm 1.38 \\
0.29-5.14\end{array}$ & $\begin{array}{c}1.81 \pm 0.71 \\
0.24-2.64\end{array}$ & 22.9 & 14.7 & 1.56 & 82.5 & 53.0 \\
\hline Pitelová & $\begin{array}{c}0.09 \pm 0.05 \\
0.05-0.18\end{array}$ & 11.4 & 2.86 & 455 & $\begin{array}{c}4.14 \pm 1.12 \\
2.32-5.74\end{array}$ & $\begin{array}{c}2.21 \pm 0.26 \\
1.86-2.66\end{array}$ & 46.9 & 25.1 & 1.87 & 121 & 64.9 \\
\hline $\begin{array}{c}\text { Sitnianska } \\
\text { lehôtka }\end{array}$ & $\begin{array}{c}0.07 \pm 0.03 \\
0.04-0.14\end{array}$ & 2.23 & 0.46 & 89.2 & $\begin{array}{c}1.08 \pm 0.34 \\
0.47-1.65\end{array}$ & $\begin{array}{c}0.78 \pm 0.27 \\
0.31-1.28\end{array}$ & 15.4 & 11.0 & 1.40 & 31.8 & 22.7 \\
\hline Skýcov & $\begin{array}{c}0.13 \pm 0.02 \\
0.10-0.17\end{array}$ & 2.04 & 0.43 & 81.5 & $\begin{array}{c}1.77 \pm 0.74 \\
0.86-3.40\end{array}$ & $\begin{array}{c}0.91 \pm 0.30 \\
0.34-1.45\end{array}$ & 13.3 & 6.81 & 1.95 & 52.0 & 26.7 \\
\hline Snina & $\begin{array}{c}0.68 \pm 0.19 \\
0.37-0.89\end{array}$ & 1.56 & -0.01 & 62.3 & $\begin{array}{c}2.32 \pm 0.37 \\
1.73-2.89\end{array}$ & $\begin{array}{c}1.70 \pm 0.39 \\
1.25-2.53\end{array}$ & 3.40 & 2.50 & 1.36 & 68.1 & 50.0 \\
\hline Solčany & $\begin{array}{c}0.13 \pm 0.05 \\
0.04-0.12\end{array}$ & 1.41 & -0.20 & 56.5 & $\begin{array}{c}2.34 \pm 0.77 \\
1.44-3.75\end{array}$ & $\begin{array}{c}1.21 \pm 0.38 \\
0.78-1.88\end{array}$ & 17.5 & 9.04 & 1.94 & 68.7 & 35.5 \\
\hline Šachtička & $\begin{array}{c}0.12 \pm 0.01 \\
0.11-0.14\end{array}$ & 2.23 & 0.56 & 89.3 & $\begin{array}{c}2.45 \pm 0.13 \\
2.23-2.65\end{array}$ & $\begin{array}{c}1.74 \pm 0.17 \\
1.47-1.99\end{array}$ & 20.0 & 14.2 & 1.41 & 71.8 & 51.0 \\
\hline Štiavnik & $\begin{array}{c}0.08 \pm 0.02 \\
0.06-0.10\end{array}$ & 1.79 & 0.12 & 71.6 & $\begin{array}{c}1.75 \pm 0.75 \\
0.98-3.05\end{array}$ & $\begin{array}{c}0.97 \pm 0.43 \\
0.44-1.50\end{array}$ & 22.5 & 12.5 & 1.80 & 51.3 & 28.4 \\
\hline Tesáre & $\begin{array}{c}0.08 \pm 0.02 \\
0.05-0.11\end{array}$ & 1.10 & -0.54 & 44.1 & $\begin{array}{c}1.21 \pm 0.28 \\
0.81-1.66\end{array}$ & $\begin{array}{c}0.88 \pm 0.22 \\
0.61-1.35\end{array}$ & 15.2 & 11.0 & 1.38 & 35.5 & 25.7 \\
\hline Zbyňov & $\begin{array}{c}0.13 \pm 0.01 \\
0.11-0.15\end{array}$ & 1.31 & -0.30 & 52.6 & $\begin{array}{c}1.93 \pm 0.66 \\
1.06-3.26\end{array}$ & $\begin{array}{c}1.06 \pm 0.47 \\
0.07-1.76\end{array}$ & 15.5 & 8.52 & 1.81 & 56.6 & 31.2 \\
\hline
\end{tabular}

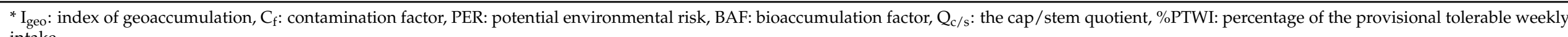
intake. 


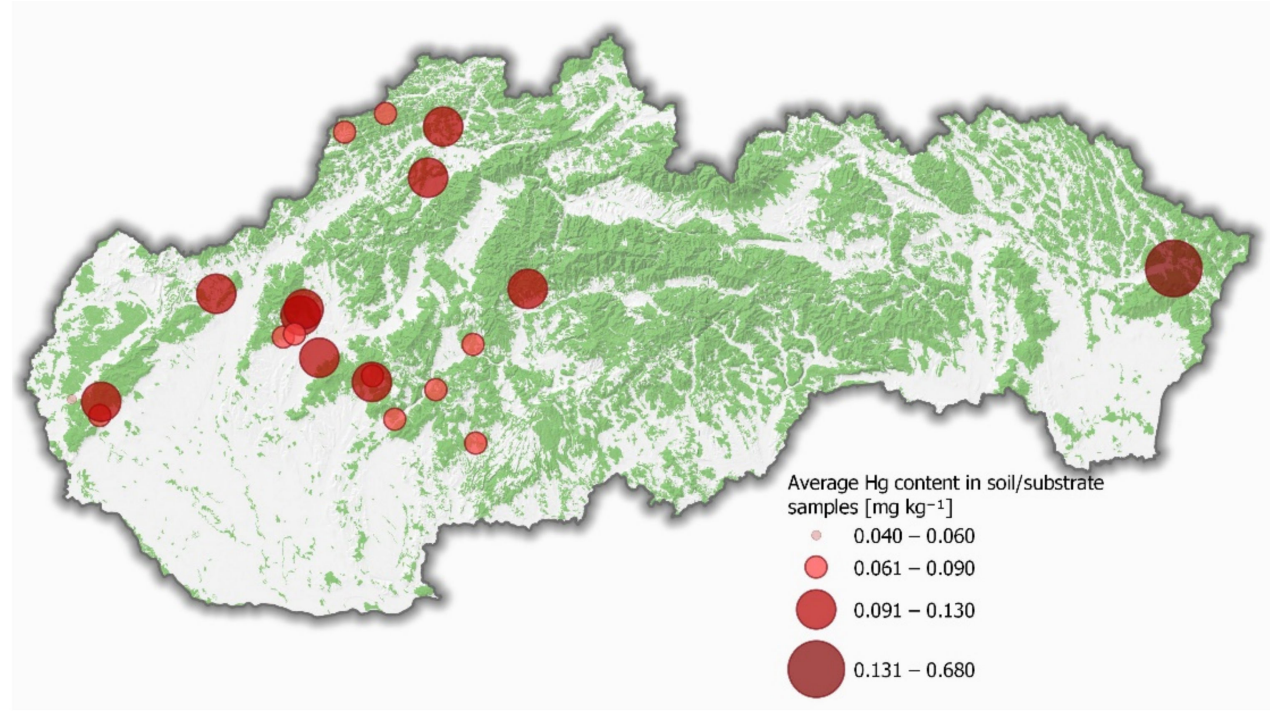

Figure 2. Distribution of mercury content in soil/substrate samples in the sampling localities.

When comparing our obtained results with the background value for mercury in soil/substrates, only samples from Snina exceeded the limit. We assume that a higher content of mercury was recorded in this locality due to chemical industries and landfills for industrial and hazardous waste located nearby. Árvay et al. [30] studied mercury contents in edible wild-growing mushroom and soil/substrate samples $(n=33)$ collected from Central Slovakia. The content of total mercury in the soil/substrate varied between 0.05 and $0.27 \mathrm{mg} \mathrm{kg}^{-1} \mathrm{DW}$, while the highest average value of $\mathrm{Hg}$ content was detected in Macrolepiota procera $(\mathrm{n}=8)$ and it was $0.13 \mathrm{mg} \mathrm{kg}^{-1}$. In another study, the content of total mercury in the underlying substrate ranged between 0.05 and $0.27 \mathrm{mg} \mathrm{kg}^{-1}(\mathrm{n}=33)$, while the average value of $\mathrm{Hg}$ content in the substrate in the case of mushroom samples with the highest content of mercury (Macrolepiota procera (Scop.) Singer, $\mathrm{n}=5$ ) was around $0.13 \mathrm{mg} \mathrm{kg}^{-1} \pm 61.7$ (mean $\pm \mathrm{RSD}$ ) ranging between 0.06 and $0.22 \mathrm{mg} \mathrm{kg}^{-1}$. The data of mercury content in the soil/substrate showed that none of the soil/substrate samples exceeded the mercury limit the soil/substrate [31]. Falandysz et al. [32] determined contents of mercury in the fruiting bodies of 15 species of higher mushrooms and soil/substrate collected from Wieluńska Upland in the northern part of Sandomierska Valley in southcentral Poland. A total of 197 mushroom samples and 227 soil samples were analyzed. Mean mercury contents in soil substrate corresponding to 15 mushroom species ( 17 samples of $M$. procera) were between $0.03 \pm 0.02$ and $0.09 \pm 0.06 \mathrm{mg} \mathrm{kg}^{-1} \mathrm{DW}$ (total range between 0.03 and $0.19 \mathrm{mg} \mathrm{kg}^{-1} \mathrm{DW}$ ). According to Falandysz and Gucia [33], the range of mercury content in topsoil samples (Poland) was between 0.01 and $0.54 \mathrm{mg} \mathrm{kg}^{-1}$ DW (means ranged between 0.02 and $0.36 \mathrm{mg} \mathrm{kg}^{-1} \mathrm{DW}$ ). More recently, Mleczek [34] measured the mean mercury content $0.06 \mathrm{mg} \mathrm{kg}^{-1} \mathrm{DW}$ (it ranged between 0.05 and 0.08 ) in the soil corresponding to M. procera from Polish forests.

\subsection{Soil Pollution}

To assess soil pollution, contamination factor, the index of geoaccumulation, and the potential ecological risk index were calculated for each sampling point. The values of $\mathrm{C}_{\mathrm{f}}$, PER, and Igeo are shown in Table 2. The contamination factor for the sampling sites was determined as low (21 sampling sites), and moderate (1 sampling site). No locality was evaluated as considerable or very high contaminated. The highest value of mercury contamination factor was found in Pitelová $\left(\mathrm{C}_{\mathrm{f}}=2.86\right)$. The index of geoaccumulation was evaluated as uncontaminated for $5 \%$ of sampling sites, almost $73 \%$ as uncontaminated or slightly contaminated, $18 \%$ as slightly, and $5 \%$ as very strongly contaminated by $\mathrm{Hg}$. The highest value of the geoaccumulation index of geoaccumulation value was found in Pitelová $\left(I_{\text {geo }}=11.4\right)$. Sefčík et al. [21] used the geoaccumulation index to study the 
contamination of Slovak soils. This study discovered that the most serious pollution was associated with mining activities and related industrial activities. The degree of the ecological risk of mercury was estimated as low risk for 1 sampling site (Král'ovce), moderate risk for 16 sampling sites, the considerable risk for 4 sampling sites, and very high risk for 1 sampling site. There was no locality where high risk was found. The potential ecological risk index was computed to detect the ecological risk of mercury in the analyzed soils/substrates. The majority of the studied soil samples showed moderate ecological risk (73\%), while $18 \%$ of analyzed samples showed considerable ecological risk. Additionally, low $(4.50 \%)$ and a very high ecological risk $(4.5 \%)$ were confirmed. There was no locality where high ecological risk was found. The highest PER value was found in Pitelová (455). Based on these facts, we can conclude that the most mercury polluted soil was in Pitelová. These findings confirmed the fact that Pitelová belongs to the 2nd environmental quality region (region with the moderately disturbed environment) [35].

Kruskal-Wallis test was conducted to examine the differences in soil according to the sampling sites/localities. It has shown that there was a statistically significant difference between tested variables $\left(p=3 \times 10^{-14}\right)$. This test (Figure S1) showed that Lozorno is significantly lower, and Snina is significantly higher compared to all analyzed localities.

\subsection{Mercury in M. procera Fruiting Bodies}

The element accumulation by wild-growing mushrooms has been the subject of numerous scientific papers around the world. Depending on the collection site, a higher, lower, or significantly differentiated ability of mushrooms to accumulate some toxic elements were reported. However, the efficiency of the element accumulation does not always depend on their content in a soil/substrate, but the element contents in such cases depend on mushroom species, genus, or the families to which they belong [36]. In this line, Kalač [18] pointed out the hypothesis that the increasing age of mycelium, up to decades in wild-growing species, and a protracted interval between fructifications significantly elevate the contents of many elements in fruiting bodies and usually higher levels occur in caps than in stems. In the present study, the mercury content in mushroom stems varied from 0.03 to $2.00 \mathrm{mg} \mathrm{kg}^{-1} \mathrm{DW}$. The maximum content was detected in Pitelová $(2.21 \pm 0.26)$ and the minimum in Hodruša-Hámre $(0.69 \pm 0.36)$. Regarding mushroom caps, Hg content varied between 0.04 and $6.29 \mathrm{mg} \mathrm{kg}^{-1} \mathrm{DW}$. The highest recorded mercury average value was $4.14 \pm 1.12 \mathrm{mg} \mathrm{kg}^{-1} \mathrm{DW}$ (Pitelová) and the lowest $0.89 \pm 0.30 \mathrm{mg} \mathrm{kg}^{-1} \mathrm{DW}$ (Král'ovce). The threshold for $\mathrm{Hg}$ in edible mushrooms (both cap and stem) is $0.75 \mathrm{mg} \mathrm{kg}^{-1} \mathrm{FW}$. When compared with our detected mercury contents, all analyzed samples (both stems and caps) did not exceed the limit.

Árvay et al. [31] analyzed M. procera from Central Slovakia (Banská Bystrica) and they detected the average content of mercury in stems $1.40(0.12-1.75) \mathrm{mg} \mathrm{kg}^{-1} \mathrm{DW}$. The highest mercury content was measured in $M$. procera cap, and the average value was 1.98 (between 0.41 and $3.20 \mathrm{mg} \mathrm{kg}^{-1} \mathrm{DW}$ ). Falandysz et al. [32] found out that Parasol Mushroom contained the greatest (compared with other species) mean mercury contents both in caps (between $4.50 \pm 1.70$ and $4.40 \pm 2.40 \mathrm{mg} \mathrm{kg}^{-1} \mathrm{DW}$ ) and stems (between $2.80 \pm 1.30$ and $\left.3.00 \pm 2.00 \mathrm{mg} \mathrm{kg}^{-1} \mathrm{DW}\right)$. The Parasol Mushroom was also characterized to have a great potential to bioaccumulate mercury from the soil as evidenced by great bioconcentration factors (BCFs), which was between $170 \pm 160$ and $130 \pm 120$ for caps, and $110 \pm 97.0$ and $89.0 \pm 92.0$ for stems. Moreover, Falandysz and Gucia [33] measured that the total mercury content ranged between 0.05 and $22.0 \mathrm{mg} \mathrm{kg}^{-1} \mathrm{DW}$ and between 0.05 and $20.0 \mathrm{mg} \mathrm{kg}^{-1} \mathrm{DW}$ in caps and stems of $M$. procera, respectively. The caps generally contained higher contents of mercury when compared to stems, and the cap to stem mercury content quotient ranged between 1.30 and 4.60. Mleczek et al. [36] determined 63 mineral elements in 17 wild-growing mushroom species from Wielkopolska Province in Poland. Detected mercury content in M. procera was $4.23 \mathrm{mg} \mathrm{kg}^{-1}$. The highest Hg contents were found in M. procera and S. bovinus. The common ranges reported in the literature for the elements of the trace elements with detrimental health effect are $<0.5-5,<0.5-10$, 
$<0.2-10,<1-5,<0.5-5$, and $<1-5 \mathrm{mg} \mathrm{kg}^{-1}$ for $\mathrm{Ag}$, $\mathrm{As}, \mathrm{Ba}, \mathrm{Cd}, \mathrm{Hg}$, and $\mathrm{Pb}$, respectively. Mleczek et al. [33] studied 34 elements in four edible mushroom species: Boletus edulis, Imleria badia, Leccinum scabrum, and Macrolepiota procera, and associated soil collected from Polish forests between 1974 and 2019. The average detected mercury content in $M$. procera was 1.74 (between 0.62 and 2.80) $\mathrm{mg} \mathrm{kg}^{-1} \mathrm{DW}$. The BCF values for M. procera ranged between 0.084 and $2.85 \mathrm{mg} \mathrm{kg}^{-1}$. A comparison of the content of the toxic metal was done and they found out that the selected species make a rather significant contribution to elements intake, and $M$. procera had a rather significant contribution to Hg intake. In general, our results (Table 2) show that $M$. procera proved its ability to accumulate $\mathrm{Hg}$. Higher mercury levels were detected in caps than in stems. This fact verifies the hypothesis stated by Kalač [18], that usually higher levels occur in caps than in stems.

Kruskal-Wallis test has shown that there was a statistically significant difference between the tested variables (stem/locality), where $p=1.9 \times 10^{-11}$. Statistical analysis (Figure S2) demonstrated that Král'ovce is significantly lower, and Pitelová is significantly higher compared to all studied localities. The relationship between cap and localities (Figure S3) showed that there is a statistically significant difference $\left(p=2 \times 10^{-14}\right)$ and Král'ovce is significantly lower, and Pitelová is significantly higher compared to all studied localities (same as for stems/localities).

The Kruskal-Wallis test with multiple pairwise comparisons was used to identify significant differences between tested variables (soil, stem, and cap samples) at the significance level of 5\%, using the asymptotic $p$-value (Figure S4). This test showed that there was a statistically significant difference among all of the analyzed variables. It has also shown that the highest mercury contents were found in mushroom caps and the lowest in the soil/substrate. These findings also indicate mercury translocation from the soil/substrate to the mushroom fruiting body.

\subsection{Bioaccumulation Factor (BAF) and Cap/Stem Quotient (Qc/s)}

Mercury can be efficiently bioaccumulated by many mushrooms [37]. The bioaccumulation factor of $M$. procera ranged between 3.40 and 46.9 (caps) and 2.50 to 33.0 (stems). These results are closely correlated with the findings of other authors, who state that species with a BAF value $>1$ accumulate the highest contents of risk elements in tubes and spores and flash of the cap [38]. In some studies, the BAF values of $M$. procera caps varied between $16 \pm 6$ and $220 \pm 110$ (total range between 0.52 and 470), and between $7.60 \pm 2.60$ and $130 \pm 96$ (total range between 0.52 and 340) for the stems [32,39]. The cap/stem quotient $\left(Q_{c / s}\right)$ was evaluated to compare the level of $\mathrm{Hg}$ translocation within the fruiting body. The quotient varied between 1.21 (Král'ovce) to 2.10 (Bojná). Falandysz et al. [39] indicate that the hymenophore of Parasol Mushroom is the morphological part, which is especially rich in mercury when compared to the rest of the fruiting body, and that the spores are probably characterized by elevated mercury accumulation in the hymenophore of this mushroom species.

\subsection{Health Risk Assessment}

In our study, \%PTWI (using mean $\mathrm{Hg}$ content) ranged between $26 \%$ and $121 \%$ (for caps) and between 20.3 and $64.9 \%$ (for stems). The highest \%PTWI for the cap was evaluated in Divina (105\%) and Pitelová (121\%). The recommended provisionally tolerable weekly intake from all of the analyzed samples was exceeded in $9 \%$ of the samples. Giannaccini et al. [40] analyzed caps and stems of 141 fruiting bodies of Parasol Mushroom and the surface layer of soils collected from 11 spatially distant areas in Northern Poland. They found out that the median mercury content in M. procera caps varied between 1.30 and $7.00 \mathrm{mg} \mathrm{kg}^{-1} \mathrm{DW}$. The estimated intake of $\mathrm{Hg}$ resulting from the consumption of 300 or $500 \mathrm{~g}$ portions of caps was assessed as $39-210$ and $65-350 \mu \mathrm{g}$, and this is equivalent to $0.65-3.5$ and $1.1-5.8 \mu \mathrm{g} \mathrm{kg}^{-1}$ body mass (BM) (a $76.0 \mathrm{~kg}$ adult). Taking into account that the provisionally tolerable weekly intake (PTWI) of mercury is $300 \mu \mathrm{g}$ (equivalent to 5.00 or $0.70 \mu \mathrm{g} \mathrm{kg}^{-1} \mathrm{BM}$ per day), and a reference dose of $0.30 \mu \mathrm{g} \mathrm{kg}^{-1} \mathrm{BM}$ per day [41,42], 
mercury in $M$. procera caps for some areas might be of concern, especially if eaten by pickers frequently in the mushrooming season.

\section{Conclusions}

This study has been carried out to investigate the accumulation of mercury in edible wild-growing $M$. procera and its corresponding soil/substrate from 22 different localities in Slovakia. The Parasol Mushroom is a species that is harvested in the wild for its unique taste. All analyzed mushroom samples of $M$. procera did not exceed the limit for $\mathrm{Hg}$ in edible mushrooms $\left(0.75 \mathrm{mg} \mathrm{kg}^{-1} \mathrm{FW}\right)$, while recommended provisionally tolerable weekly intake was exceeded in $9 \%$ of the analyzed samples. The level of ecological load of the monitored localities showed that the analyzed soils/substrates were polluted with mercury. The potential of Parasol Mushrooms to bioaccumulate certain metals, e.g., mercury in fruiting bodies can be very or extremely high. The contamination factor for the sampling sites was determined as low and moderate. The degree of the ecological risk of mercury was estimated as low risk (1 sampling site), moderate risk (16 sampling sites), considerable risk (4 sampling sites), and very high risk (1 sampling site). The majority of the studied soil samples showed moderate ecological risk and considerable ecological risk. Moreover, low $(4.50 \%)$ and very high ecological risks $(4.5 \%)$ were confirmed. The highest value contamination factor, geoaccumulation index, and PER were determined in Pitelová. This reaffirms that Pitelová belongs to the regions with a moderately disturbed environment in Slovakia. The current study validates that $M$. procera can uptake and accumulate $\mathrm{Hg}$ (and other elements) from its underlying soil/ substrate. Information provided by our study can bring a more comprehensive understanding of mercury transmission from the soil/substrate to the mushroom fruiting bodies. Concurrently, it can fill the vacancy and provide information about a significant detrimental impact on the environment, as well as consumers' health resulting from long-term consumption of contaminated mushrooms.

Supplementary Materials: The following are available online at https://www.mdpi.com/article/10 .3390/jof7090772/s1, Figure S1: Mercury concentrations in soils/substrates, concerning localities. The horizontal line presents the average concentration for all samples, Figure S2: Mercury concentrations in mushroom stems, concerning localities. The horizontal line presents the average concentration for all samples, Figure S3: Mercury concentrations in mushroom caps, concerning localities. The horizontal line presents the average concentration for all samples, Figure S4: Mercury concentrations in soils/substrates and mushroom body parts (caps and stems).

Author Contributions: I.J.: Investigation, Analysis, Writing.; M.Š.: Investigation, Statistical analysis.; M.H.: GIS processing, Review.; L.D.: Investigation, Statistical analysis; H.F.: Investigation.; V.K.: Review.; T.L.: Review.; J.Á.: Investigation, Editing, and Revising, Project administration. All authors have read and agreed to the published version of the manuscript.

Funding: This work was supported by the Ministry of Education, Science, Research and Sport of the Slovak Republic project VEGA no. 1/0591/18 and 1/0326/18.

Institutional Review Board Statement: Not applicable.

Informed Consent Statement: Not applicable.

Data Availability Statement: The datasets analyzed during the current study are available from the corresponding author on reasonable request.

Acknowledgments: This project was supported by the Grant Agency of The Slovak University of Agriculture in Nitra, the project number 17-GASPU-2021: Possibilities of reducing the level of contamination of edible wild-growing mushrooms from environmentally polluted areas of Slovakia while preserving their valuable biologically active substances.

Conflicts of Interest: The authors declare no conflict of interest. 


\section{References}

1. Haro, A.; Trescastro, A.; Lara, L.; Fernández-Fígares, I.; Nieto, R.; Seiquer, I. Mineral elements contents of wild growing edible mushrooms from the southeast of Spain. J. Food Compos. Anal. 2020, 91, 103504. [CrossRef]

2. Kunca, V.; Pavlík, M. Fruiting Body Production of, and Suitable Environmental Ranges for, Growing the Umbrella Polypore Medicinal Mushroom, Polyporus umbellatus (Agaricomycetes) in Natural Conditions in Central Europe. Int. J. Med. Mushrooms 2019, 2, 121-129. [CrossRef]

3. Kunca, V.; Čiliak., M. Habitat preferences of Hericium erinaceus in Slovakia. Fungal Ecol. 2017, 27, 189-192. [CrossRef]

4. Árvay, J.; Demková, L.; Hauptvogl, M.; Michalko, M.; Bajčan, D.; Stanovič, R.; Tomáš, J.; Hrstková, M.; Trebichalský, P. Assessment of Environmental and Health Risks in Former Polymetallic Ore Mining and Smelting Area, Slovakia: Spatial Distribution and Accumulation of Mercury in Four Different Ecosystems. Ecotoxicol. Environ. Saf. 2017, 144, 236-244. [CrossRef]

5. Melgar, M.J.; Alonso, J.; García, M.A. Cadmium in edible mushrooms from NW Spain: Bioconcentration factors and consumer health implications. Food Chem. Toxicol. 2016, 88, 13-20. [CrossRef] [PubMed]

6. Bahadori, M.B.; Sarikurkcu, C.; Yalcin, O.U.; Cengiz, M.; Gungor, H. Metal concentration, phenolics profiling, and antioxidant activity of two wild edible Melanoleuca mushrooms (M. cognata and M. stridula). Microchem. J. 2019, 150, 104172. [CrossRef]

7. Mleczek, M.; Siwulski, M.; Stuper-Szablewska, K.; Rissmann, I.; Sobieralski, K.; Goliński, P. Accumulation of elements by edible mushroom species: Part I. Problem of trace element toxicity in mushrooms. J. Environ. Sci. Health 2013, 48, 69-81. [CrossRef] [PubMed]

8. Kokkoris, V.; Massas, I.; Polemis, E.; Koutrotsios, G.; Zervakis, G.I. Accumulation of heavy metals by wild edible mushrooms with respect to soil substrates in the Athens metropolitan area (Greece). Sci. Total Environ. 2019, 685, 280-296. [CrossRef]

9. Melgar, M.J.; Alonso, J.; García, M.A. Mercury in edible mushrooms and underlying soil: Bioconcentration factors and toxicological risk. Sci. Total Environ. 2009, 407, 5328-5334. [CrossRef]

10. Falandysz, J.; Chudzińska, M.; Barałkiewicz, D.A.N.U.T.A.; Saba, M.; Wang, Y.; Zhang, J. Occurrence, variability and associations of trace metallic elements and arsenic in sclerotia of medicinal Wolfiporia extensa from polymetallic soils in Yunnan, China. Acta Pol. Pharm. Drug Res 2017, 74, 1379-1387.

11. Falandysz, J.; Hanć, A.; Barałkiewicz, D.; Zhang, J.; Treu, R. Metallic and metalloid elements in various developmental stages of Amanita muscaria (L.) Lam. Fungal Biol. 2020, 124, 174-182. [CrossRef] [PubMed]

12. Falandysz, J.; Sapkota, A.; Dryżałowska, A.; Mędyk, M.; Feng, X. Analysis of some metallic elements and metalloids composition and relationships in parasol mushroom Macrolepiota procera. Environ. Sci. Pollut. Res. 2017, 24, 15528-15537. [CrossRef]

13. Gucia, M.; Jarzyńska, G.; Rafał, E.; Roszak, M.; Kojta, A.K.; Osiej, I.; Falandysz, J. Multivariate analysis of mineral constituents of edible Parasol Mushroom (Macrolepiota procera) and soils beneath fruiting bodies collected from Northern Poland. Environ. Sci. Pollut. Res. 2012, 19, 416-431. [CrossRef] [PubMed]

14. Vukojević, V.; Đurđić, S.; Stefanović, V.; Trifković, J.; Čakmak, D.; Perović, V.; Mutić, J. Scandium, yttrium, and lanthanide contents in soil from Serbia and their accumulation in the mushroom Macrolepiota procera (Scop.) Singer. Environ. Sci. Pollut. Res. 2019, 26, 5422-5434. [CrossRef] [PubMed]

15. Hsu-Kim, H.; Eckley, C.S.; Achá, D.; Feng, X.; Gilmour, C.C.; Jonsson, S.; Mitchell, C.P. Challenges and opportunities for managing aquatic mercury pollution in altered landscapes. Ambio 2018, 47, 141-169. [CrossRef] [PubMed]

16. Xu, J.; Zhang, J.; Lv, Y.; Xu, K.; Lu, S.; Liu, X.; Yang, Y. Effect of soil mercury pollution on ginger (Zingiber officinale Roscoe): Growth, product quality, health risks and silicon mitigation. Ecotoxicol. Environ. Saf. 2020, 195, 110472. [CrossRef]

17. Tang, W.L.; Liu, Y.R.; Guan, W.Y.; Zhong, H.; Qu, X.M.; Zhang, T. Understanding mercury methylation in the changing environment: Recent advances in assessing microbial methylators and mercury bioavailability. Sci. Total Environ. 2020, 714, 136827. [CrossRef] [PubMed]

18. Kalač, P. Mineral Composition and Radioactivity of Edible Mushrooms; Academic Press: Amsterdam, The Netherlands, 2019; ISBN 978-0-12-817565-1.

19. Nayab, G.U.L.; Sardar, K.H.A.N.; Abbas, K.H.A.N.; Nawab, J.; Sarwar, A.; Nida, G.U.L. Organic and Inorganic Mercury in Biological Samples of Flouresecent Lamp Industries Workers and Health Risks. Biomed. Environ. Sci. 2020, 33, 89-102. [CrossRef]

20. Hakanson, L. An Ecological Risk Index for Aquatic Pollution Control. Water Res. 1980, 14, 975-1001. [CrossRef]

21. Šef̌́ík, P.; Pramuka, S.; Gluch, A. Assessment of soil contamination in Slovakia according index of geoaccumulation. Agriculture 2008, 54, 119-130.

22. Islam, S.; Ahmed, K.; Masunaga, S. Potential ecological risk of hazardous elements in different land-use urban soils of Bangladesh. Sci. Total Environ. 2015, 512, 94-102. [CrossRef] [PubMed]

23. Wu, S.; Peng, S.; Zhang, X.; Wu, D.; Luo, W.; Zhang, T.; Wu, L. Levels and health risk assessments of heavy metals in urban soils in Dongguan, China. J. Geochem. Explor. 2015, 148, 71-78. [CrossRef]

24. Müller, G. Index of geoaccumulation in sediments of the Rhine River. Geojournal 1969, 2, 108-118.

25. Dryźalowska, A.; Falandysz, J. Bioconcentration of mercury by mushroom Xerocomus chrysenteron from the spatially distinct locations: Levels, possible intake and safety. Ecotoxicol. Environ. Saf. 2014, 107, 97-102. [CrossRef] [PubMed]

26. Joint, F.A.O.; World Health Organization; WHO Expert Committee on Food Additives. Safety evaluation of certain food additives/prepared by the by the Seventy Fourth Meeting of the Joint FAO/WHO Expert Committee on Food Additives (JECFA). 2012. Available online: https:/ / books.google.ro/books?hl=ro\&lr=\&id=YFAMU9qYD_YC\&oi=fnd\&pg=PP7\&ots=e5skGh31Ln\& sig=W99eNu8GUWHIWsG-ooJzM1dlkws\&redir_esc=y\#v=onepage\&q\&f=false (accessed on 2 July 2021). 
27. Statistical Organization of Slovak Republic 2019. Food Consumption in the Slovak Republic 2018. Available online: www. statistics.sk (accessed on 17 December 2020).

28. RStudio Team. RStudio: Integrated Development for R. RStudio; PBC: Boston, MA, USA, 2020. Available online: http://www. rstudio.com/ (accessed on 2 July 2021).

29. Addinsoft. XLSTAT, Analyse de Données et Statistique avec MS Excel; Addinsoft: New York, NY, USA, 2014.

30. Árvay, J.; Tomáš, J.; Hauptvogl, M.; Massányi, P.; Harangozo, L'. Human Exposure to Heavy Metals and Possible Public Health Risks Via Consumption of Wild Edible Mushrooms from Slovak Paradise National Park, Slovakia. J. Environ. Sci. Health Part B 2015, 50, 833-848. [CrossRef] [PubMed]

31. Árvay, J.; Záhorcová, Z.; Tomáš, J.; Hauptvogl, M.; Stanovič, R.; Harangozo, L'. Mercury in edible wild-grown mushrooms from historical mining area-Slovakia: Bioaccumulation and risk assessment. J. Microbiol. Biotechnol. Food Sci. 2021, 1-4. [CrossRef]

32. Falandysz, J.; Bielawski, L.; Kawano, M.; Brzostowski, A.; Chudzyński, K. Mercury in mushrooms and soil from the Wieluńska Upland in south-central Poland. J. Environ. Sci. Health Part A 2002, 37, 1409-1420. [CrossRef]

33. Falandysz, J.; Gucia, M. Bioconcentration factors of mercury by Parasol Mushroom (Macrolepiota procera). Environ. Geochem. Health 2008, 30, 121-125. [CrossRef]

34. Mleczek, M.; Siwulski, M.; Budka, A.; Mleczek, P.; Budzyńska, S.; Szostek, M.; Goliński, P. Toxicological risks and nutritional value of wild edible mushroom species-a half-century monitoring study. Chemosphere 2021, 263, 128095. [CrossRef] [PubMed]

35. Environmental Regionalization of the Slovak Republic. 2016. Available online: https://www.minzp.sk/files/environmentalnaregionalizacia-sr.pdf (accessed on 17 December 2017).

36. Mleczek, M.; Budka, A.; Kalač, P.; Siwulski, M.; Niedzielski, P. Family and species as determinants modulating mineral composition of selected wild-growing mushroom species. Environ. Sci. Pollut. Res. 2020, 1-16. [CrossRef]

37. Falandysz, J.; Borovička, J. Macro and trace mineral constituents and radionuclides in mushrooms: Health benefits and risks. Appl. Microbiol. Biotechnol. 2013, 97, 477-501. [CrossRef] [PubMed]

38. Zocher, A.L.; Kraemer, D.; Merschel, G.; Bau, M. Distribution of major and trace elements in the bolete mushroom Suillus luteus and the bioavailability of rare earth elements. Chem. Geol. 2018, 483, 491-500. [CrossRef]

39. Falandysz, J.; Gucia, M.; Mazur, A. Content and bioconcentration factors of mercury by Parasol Mushroom Macrolepiota procera. J. Environ. Sci. Health Part B 2007, 42, 735-740. [CrossRef]

40. Giannaccini, G.; Betti, L.; Palego, L.; Mascia, G.; Schmid, L.; Lanza, M.; Lucacchini, A. The trace element content of top-soil and wild edible mushroom samples collected in Tuscany, Italy. Environ. Monit. Assess. 2012, 184, 7579-7595. [CrossRef] [PubMed]

41. World Health Organization. Evaluation of Certain Food Additives and Contaminants. Twenty-Second Report of the Joint FAO/WHO Expert Committee on Food Additives; No. 631; World Health Organization: Geneva, Switzerland, 1978.

42. EPA, US. Toxicological Review of Zinc and Compounds; US Environmental Protection Agency: Washington, DC, USA, 2005. 